\title{
Successful treatment of severe atenolol overdose with calcium chloride
}

\author{
John O'Grady, MD; Scott Anderson, MD; Derrick Pringle, MD
}

\begin{abstract}
Atenolol, a selective $\beta_{1}$-adrenergic antagonist, is commonly used to treat hypertension, ischemic heart disease and cardiac dysrhythmias. Few cases of severe atenolol intoxication have been described, and only one of these reports discussed the use of calcium chloride as a treatment. We present a case of atenolol overdose associated with shock and first-degree heart block, in which administration of calcium chloride led to dramatic improvement after failure of conventional treatment. In addition, we discuss the pharmacokinetics, toxicology and management of $\beta$-blocker overdose, focusing on the possible role of calcium chloride.

RÉSUMÉ

L'aténolol, un inhibiteur des récepteurs $\beta_{1}$-adrénergiques, est utilisé couramment pour traiter I'hypertension, I'insuffisance coronarienne et les dysrythmies cardiaques. La littérature fait état de peu de cas d'intoxication à l'aténolol et un seul de ces rapports discutait du recours au chlorure de calcium comme forme de traitement. Nous présentons un cas d'intoxication à l'aténolol accompagnée d'un état de choc et d'un bloc cardiaque du premier degré pour lequel l'administration de chlorure de calcium eut des résultats remarquables après l'échec du traitement conventionnel. De plus, nous présentons la pharmacocinétique, la toxicologie et la prise en charge de l'intoxication aux $\beta$-bloquants, notre propos étant axé sur le rôle possible du chlorure de calcium.
\end{abstract}

Key words: atenolol, $\beta$-blocker, intoxication

\section{Introduction}

Atenolol is a selective $\beta_{1}$-adrenergic antagonist that lacks intrinsic sympathomimetic activity. It has a longer halflife than most similar agents, ${ }^{1,2}$ it is hydrophilic, and its brain penetration is limited. Atenolol and other $\beta_{1^{-}}$ adrenergic receptor antagonists are widely prescribed for hypertension, ischemic heart disease and certain dysrhythmias.

Only a few severe atenolol overdoses have been documented, ${ }^{3-14}$ and in only one case ${ }^{10}$ was therapeutic use of calcium chloride reported. In that case, calcium was administered 48 hours after atenolol ingestion, by which time the $\beta$-blocker levels may have been negligible. Also, only one report of overdose with propranolol, a nonselective $\beta_{1}$ adrenergic antagonist, described the use of calcium chloride as possible treatment. ${ }^{15}$ Calcium has also been used in the treatment of acebutolol and nadolol intoxications. In the former case, there was a transient increase in blood pressure after calcium was administered,${ }^{16}$ while in the latter, blood pressure gradually increased to normal within 2 hours of the calcium gluconate infusion. ${ }^{17}$

We report a case in which atenolol overdose was successfully treated with calcium chloride. This case and previous reports suggest that calcium chloride has a role in the treatment of $\beta$-blocker toxicity and that it may, in some cases, obviate the need for nonpharmacologic measures such as hemodialysis. 


\section{Case report}

A 50-year-old woman with a long-standing psychiatric history was left alone by her husband at $9 \mathrm{am}$. When he returned at $1 \mathrm{pm}$, he found her unresponsive on the floor, with a suicide note and several empty pill bottles nearby, including acetaminophen, clonazepam, desipramine (old prescription) and atenolol (recent prescription). Her past medical history was remarkable for remote coronary artery bypass grafting, peptic ulcer disease and migraine headaches.

The paramedics attending the patient found her bradycardic, hypotensive and responsive only to deep pain. On arrival at the emergency department (ED) her heart rate was 50 beats/min and her blood pressure was $70 / 50 \mathrm{~mm}$ $\mathrm{Hg}$. Rhythm strip and electrocardiography (ECG) confirmed narrow complex bradycardia with first-degree heart block.

In the ED, she was promptly and easily intubated without medication, but aggressive attempts to increase her blood pressure were unsuccessful, and the following agents were administered without effect: normal saline boluses, atropine, ephedrine, high-dose titrated dopamine (in excess of $200 \mu \mathrm{g} / \mathrm{kg}$ per minute), high-dose epinephrine (in excess of $200 \mu \mathrm{g} / \mathrm{kg}$ per minute) and glucagon (11 mg, given as 1-, 5- and 5-mg boluses). Despite these, the patient's systolic blood pressure remained in the range of 50-60 mm Hg until $1 \mathrm{~g}$ of calcium chloride was administered, at which point it rose dramatically to $100-120 \mathrm{~mm}$ $\mathrm{Hg}$. Thirty minutes later her hypotension recurred, and a second dose of calcium chloride resulted in an equally dramatic blood pressure response.

The remainder of the patient's hospital course was unremarkable. Inotropes were titrated off over the ensuing 3 hours, she was extubated during the first night, a psychiatric evaluation was completed, and she was discharged on day 4 with appropriate follow-up.

\section{Discussion}

\section{Pharmacokinetics of $\beta$-blockers}

Atenolol, a selective $\beta_{1}$-adrenergic receptor antagonist, has an oral bioavailability of about $56 \%$. Although it is poorly absorbed, most of the absorbed drug reaches the systemic circulation because of the lack of a first-pass effect. Atenolol's volume of distribution is $0.95 \mathrm{~L} / \mathrm{kg}$ and less than $5 \%$ is bound to plasma proteins. ${ }^{1}$ Most of the drug is excreted unchanged in urine with an elimination half-life of 5 to 8 hours. The usual atenolol dose for hypertensive therapy is 50 to $100 \mathrm{mg}$ daily but, for the reasons discussed above, this must be adjusted down in patients with low creatinine clearance. $^{2}$

Wadworth and colleagues ${ }^{2}$ determined that, to achieve a $15 \%$ reduction in exercise heart rate with atenolol, the required effective plasma concentration is $376 \mathrm{nmol} / \mathrm{L}$, but to achieve a $30 \%$ reduction requires $3760 \mathrm{nmol} / \mathrm{L}$ - a 10fold increase. Atenolol's therapeutic plasma concentration range is 752 to $1880 \mathrm{nmol} / \mathrm{L},{ }^{1}$ but there is wide variability in patient responses to $\beta_{1}$-adrenergic antagonists, and blood levels correlate poorly with clinical manifestations. ${ }^{18}$ To illustrate, atenolol doses up to $1200 \mathrm{mg}$ and propranolol doses up to $4000 \mathrm{mg} /$ day have been tolerated without significant clinical manifestations ${ }^{8,11}$ but, in one case, a 500$\mathrm{mg}$ atenolol overdose caused hemodynamic instability ${ }^{6}$ and, in another, a 1000-mg atenolol overdose caused cardiac sinus pauses that persisted for 34 hours. ${ }^{4}$ In a particularly severe case, $5000 \mathrm{mg}$ of atenolol led to ventilatory suppression requiring mechanical ventilation, with a plasma concentration of $35338 \mathrm{nmol} / \mathrm{L} .{ }^{3}$ Of note, hemodynamic stability was maintained in this case without pharmacologic treatment.

\section{Clinical findings, pathophysiology and experimental models}

$\beta$-Blockers inhibit adrenergic receptors and reduce sympathetic nerve activity in various body tissues. This leads to a predictable constellation of signs and symptoms, including bradycardia, hypotension, low cardiac output, cardiac failure, cardiogenic shock, bronchospasm, ventilatory depression, and hypoglycemia, ${ }^{3,19}$ although the last of these occurs rarely.

Cardiotoxicity is mainly due to ion dyshomeostasis, cardiac hyperpolarization and membrane stabilization. ${ }^{20}$ This mechanism was substantiated by Kerns and associates, ${ }^{21}$ who perfused isolated rat hearts with either propranolol or atenolol. Both agents had negative chronotropic effects and rendered the hearts refractory to pacing, but atenolol also reduced myocardial contractility. Subsequent treatment with low extracellular potassium $\left(\mathrm{K}^{+}, 2.3 \mathrm{mmol} / \mathrm{L}\right)$ and high extracellular sodium $\left(\mathrm{Na}^{+}, 160 \mathrm{mmol} / \mathrm{L}\right)$ increased heart rate and restored the ability to pace.

Langemeijer and colleagues ${ }^{22}$ treated isolated, spontaneously beating rat hearts with propranolol and demonstrated a dose-dependent decrease in myocardial contractility. They then repeated the experiment, comparing reserpine-treated and non-reserpine-treated hearts (reserpine is a catecholamine-depleting agent). Both responded in the same way, which suggests that propranolol's negativeinotropic effects are not explained by actions on the $\beta$ adrenergic receptor. Langemeijer and colleagues also 
showed that propranolol's effects on contractility were less pronounced in a medium enriched with calcium $\left(\mathrm{Ca}^{++}\right)$, which suggests that its negative inotropism is due to or at least influenced by calcium. Of interest, a little known metabolic manifestation of $\beta$-blocker overdose is hypocalcemia, probably mediated through blockage of parathyroid hormone. ${ }^{23,24}$ Given what is known about the $\beta$-blocker and calcium interactions, it is not surprising that, in a canine $\beta$ blocker overdose model, calcium chloride administration significantly improved blood pressure, stroke volume and cardiac index. ${ }^{25}$

\section{Drug interactions}

The patient in this case had also ingested acetaminophen, clonazepam and desipramine, which might have affected the presentation. However, acetaminophen causes hepatotoxicity rather than cardiac effects and would not produce the degree of cardiovascular compromise seen in this patient. ${ }^{26}$ Clonazepam, a benzodiazepine, has few cardiovascular effects and is relatively safe in overdoses. ${ }^{1}$ It causes central nervous system (CNS) depression and is more likely to produce drowsiness or coma. Desipramine, a tricyclic antidepressant, causes anticholinergic effects, CNS depression, catecholamine depletion, cardiotoxicity and orthostatic hypotension, but tricyclic overdoses typically present with supraventricular tachycardia and, in significant cases, prolonged QRS duration on ECG. ${ }^{27}$ Given that our patient had access to very little desipramine and did not exhibit anticholinergic findings or QRS widening, it is unlikely that her cardiovascular compromise was induced by the tricyclic agent.

\section{Management}

Glucagon has long been the treatment of choice for massive $\beta$-blocker overdose. The activation of glucagon receptors, through G-protein-mediated mechanisms, stimulates adenyl cyclase and increases intracellular cyclic adenosine monophosphate independent of $\beta_{1}$-adrenergic receptors. ${ }^{19}$ Other treatments for $\beta$-blocker overdose include $\beta_{1}$-agonists, atropine, phosphodiasterase inhibitors (e.g., aminophylline, amrinone and milrinone), cardiac pacing and hemodialysis. Hemodialysis should be reserved for removal of renally excreted $\beta$-blockers that are minimally protein bound in patients who are refractory to pharmacologic therapy. ${ }^{9}$

Two prior case reports ${ }^{10,15}$ describe successful treatment of serious $\beta$-blocker overdose with calcium chloride. In the first case, ${ }^{15}$ a 22 -year-old woman ingested a large amount of propranolol as well as a smaller amount of metoclopramide and alcohol. Upon arrival in the ED she was given epinephrine, atropine, lidocaine and sodium bicarbonate; then cardioversion was performed for ventricular tachycar- dia. After defibrillation she developed electromechanical dissociation (EMD) with wide-complex sinus rhythm. At this time, $1 \mathrm{~g}$ of calcium chloride was administered and, within 30 seconds, the patient's QRS complexes normalized and she regained palpable pulses with a blood pressure of $80 / 40 \mathrm{~mm} \mathrm{Hg}$. Five and 10 minutes later, she slipped back into EMD, but both episodes were successfully treated with repeat doses of calcium chloride. After the second recurrence, a calcium chloride infusion was initiated and titrated according to blood pressure and ECG pattern. The infusion was stopped after 60 minutes, at which point electrolytes, blood glucose and plasma osmolality were normal. The serum calcium level was 3.29 $\mathrm{mmol} / \mathrm{L}$ (normal 2.12-2.62 $\mathrm{mmol} / \mathrm{L}$ ). The patient was subsequently transferred to the intensive care unit and discharged home 48 hours after admission with no neurologic sequelae.

The second case ${ }^{10}$ involved a 20 -year-old woman who ingested 1800 to $2500 \mathrm{mg}$ of atenolol, as well as $500 \mathrm{mg}$ of hydrochlorothiazide, $240 \mathrm{mg}$ of fluoxetine and $40 \mathrm{~mL}$ of chlordesmetildiazepam. On arrival in the ED, the physical findings were normal, blood pressure was $70 / 60 \mathrm{~mm}$ $\mathrm{Hg}$, and her ECG was within normal limits, but 16 hours later, systolic blood pressure had dropped to $40 \mathrm{~mm} \mathrm{Hg}$ and pulse rate to 38 beats/min. The ECG showed a junctional rhythm with left bundle branch block and a prolonged QTc interval. At that time the serum atenolol concentration was $32000 \mathrm{ng} / \mathrm{mL}$. Epinephrine, magnesium sulfate, potassium chloride, and glucagon infusions were started, and a temporary transvenous pacemaker was inserted. Her condition transiently improved, but 48 hours after the overdose her heart rate dropped to 45 beats/min and she became pulseless. Epinephrine and calcium chloride (1 $\mathrm{mg}$ of each) were administered through the central line, and pulses rapidly returned. She then slipped back into EMD and was treated successfully with $1 \mathrm{~g}$ of calcium chloride followed by a calcium chloride infusion. On day 12 she was discharged with no cardiac, neurological or renal sequelae.

\section{Treatment guidelines}

The Resuscitation Council of the United Kingdom ${ }^{28}$ and the American Heart Association guidelines for cardiopulmonary resuscitation and emergency cardiac care ${ }^{29}$ both recommend the use of calcium in EMD associated with hyperkalemia, hypocalcemia and calcium antagonist overdose. It should be noted that the protocols for advanced cardiac life support do not directly govern the treatment of drug poisonings, but rather give algorithms for the treatment of hypotension, a known toxic effect of $\beta$-blockers. 


\section{Conclusion}

$\beta_{1}$-Adrenergic blocking agents are potentially lethal in overdose situations. In these cases physicians should enlist the help of the local poison control centre and should consider treatment with $\beta_{1}$-agonists, atropine, glucagon, phosphodiasterase inhibitors, cardiac pacing and hemodialysis. The case reports presented suggest that calcium chloride is an effective therapy and should be considered in cases of significant $\beta$-blocker intoxication.

An abstract for this report was presented at the 2001 scientific meeting of the Canadian Association of Emergency Physicians in Calgary, Alta., Mar. 21-24, 2001.

\section{References}

1. Hoffman BB, Lefkowitz RJ. Catecholamines, sympathomimetic drugs, and adrenergic receptor antagonists. In: Goodman LS, Gilman A, Hardman JG, Limbird LE. Goodman \& Gilman's the pharmacological basis of therapeutics. 9th ed. New York: McGraw-Hill; 1996. p. 199-248.

2. Wadworth AN, Murdoch D, Brogden RN. Atenolol: a reappraisal of its pharmacological properties and therapeutic use in cardiovascular disorders. Drugs 1991;42:468-510.

3. Montgomery AB, Stager BSN, Schoene RB. Marked suppression of ventilation while awake following massive ingestion of atenolol. Chest 1985;88:920-1.

4. Weinstein RS, Cole S, Knaster HB, Dalbert T. Beta blocker overdose with propranolol and with atenolol. Ann Emerg Med $1985 ; 14: 161-3$

5. Freestone S, Thomas HM, Bhamra RK, Dyson EH. Severe atenolol poisoning: treatment with prenalterol. Human Toxicol 1986;5:343-5.

6. Abbasi IA, Sorsby. Prolonged toxicity from atenolol overdose in an adolescent. Clin Pharm 1986;5:836-7.

7. Saitz R, Williams BW, Farber HW. Atenolol-induced cardiovascular collapse treated with hemodialysis. Crit Care Med 1991;19:116-8.

8. Stinson J, Walsh M, Feely J. Ventricular asystole and overdose with atenolol. BMJ 1992;305:693.

9. Delima LGR, Kharasch ED, Butler S. Successful pharmacologic treatment of massive atenolol overdose: sequential hemodynamics and plasma atenolol concentration. Anesthesiology 1995;83:204-7.

10. Pertoldi F, D'Orlando L, Mercante WP. Electromechanical dissociation 48 hours after atenolol overdose: usefulness of calcium chloride. Ann Emerg Med 1998;31:777-81.

11. Boakes AJ, Boerre BH. Suicidal attempts with $\beta_{1}$-adrenoreceptor blocking agents [letter]. BMJ 1973;4:675.

12. Shanahan FLJ, Counihan TB. Atenolol self-poisoning [letter]. BMJ 1978;2:773.
13. Giang D, Isaeff DM. Atenolol overdose in a patient with progressive renal failure. West J Med 1986;145:101-3.

14. Reith DM, Dawson AH, Epid D, Whyte IM, Buckley NA, Sayer GP. Relative toxicity of beta blockers in overdose. J Toxicol Clin Toxicol 1996;34:273-8.

15. Brimacombe JR, Scully M, Swainston R. Propranolol overdose: a dramatic response to calcium chloride. Med J Aust 1991;155: $267-8$.

16. Sangster B, de Wildt D, van Dijk A, Klein S. A case of acebutolol intoxication. J Toxicol Clin Toxicol 1983;20(1):69-77.

17. Ehgartner GR, Zelinka MA. Hemodynamic instability following intentional nadolol overdose. Arch Intern Med 1988;148(4):801-2.

18. Love JN. Beta blocker toxicity after overdose: When do symptoms develop in adults? J Emerg Med 1994;12:799-802.

19. Frishman WH, Jacob H, Eisenberg E, Ribner H. Clinical pharmacology of the new beta-adrenergic blocking drugs. Part 8 . Self-poisoning with beta-adrenoreceptor blocking agents: recognition and management. Am Heart J 1979;98(6):798-811.

20. Henry JA, Cassidy SL. Membrane stabilizing activity: a major cause of fatal poisoning. Lancet 1986;1(8495):1414-7.

21. Kerns W, Ransom M, Tomaszewski C, Kline J, Raymond R. The effects of extracellular ions on beta-blocker cardiotoxicity. Toxicol Appl Pharmacol 1996;137:1-7.

22. Langemeijer JJ, deWildt DJ, de Groot G, Sangster B. Calcium interferes with the cardiodepressive effects of beta blocker overdose in isolated rat hearts. J Toxicol Clin Toxicol 1986;24:111-33.

23. Amundson DE, Brodine SK. A fatal case of propranolol poisoning. Drug Intell Clin Pharm 1988;22:781-2.

24. Ganong WF. Hormonal control of calcium metabolism and the physiology of the bone. In: Review of medical physiology. 18th ed. Stamford (CT): Appleton \& Lange Publications; 1997. p. 359-71.

25. Love JN, Hanfling D, Howell JM. Hemodynamic effects of calcium chloride in a canine model of acute propranolol intoxication. Ann Emerg Med 1996;28:1-6.

26. Thomas SH. Paracetamol (acetaminophen) poisoning. Pharmacol Ther 1993;60:91-120.

27. Boehnert MT, Lovejoy FH Jr. Value of the QRS duration versus the serum drug level in predicting seizures and ventricular arrhythmias after an acute overdose of tricyclic antidepressants. N Engl J Med 1985;313:474-9.

28. Chamberlain DA. Advanced life support. Revised recommendations of the Resuscitation Council (UK). BMJ 1989;299:446-8.

29. Emergency Cardiac Care Committee and Subcommittees, American Heart Association. Guidelines for cardiopulmonary and emergency cardiac care, part III: adult advanced cardiac life support. JAMA 1992;268:2199-241.

Correspondence to: Dr. Scott Anderson, EMA Office, London Health Sciences Centre, 375 South St., London ON N6A 4G5; fax 519 667-6769, sanderso@julian.uwo.ca 